\title{
PENGARUH PENETAPAN HARGA JUAL TERHADAP VOLUME PENJUALAN
}

\author{
lis Nurlela', Rini Agustin Eka Yanti', Firman Aryansyah ${ }^{3}$ \\ 1,2,3 Program Studi Pendidikan Akuntansi, Universitas Galuh, Jl. R. E. Martadinata No.150, Ciamis, Indonesia \\ Email :iisnurlela23@gmail.com
}

\begin{abstract}
The development of the business world is currently running rapidly, indirectly creating competition in the marketing field. The more consumers who are satisfied with the goods or services offered, the sales volume at the company will increase. Factors that affect sales volume are (1) price, (2) promotion, (3) product offered, (4) distribution channel, (5) quality. Price is one of the main considerations when consumers will buy a product they want. The purpose of this study is to find out: (1) an overview of the selling price fixing carried out by Tungku Café and Resto in Banjar City, (2) an overview of sales volume at a Café and Resto Furnace in Banjar City, (3) the effect of selling price fixing on volume sales at the Tungku Café and Resto Banjar city. The research method used is a descriptive method using direct data collection techniques through observation and interviews. The results showed that (1) the determination of the selling price using the cost plus pricing method fluctuated with an average margin of $23 \%$, (2) the sales volume fluctuated with an average sale of about 38 products sold, (3) the magnitude of the effect of determining the selling price on the sales volume of $57.76 \%$ (coefficient of determination). The results of the hypothesis test are known that $t$ count is greater than $t$ table $(3,697 \geq 2,228)$ meaning Ho is rejected and $\mathrm{Hi}$ is accepted. This shows that price has a significant effect on sales volume volume
\end{abstract}

Keywords: Pricing, cost plus pricing, sales volume.

\section{ABSTRAK}

Perkembangan dunia usaha saat ini berjalan dengan pesat, secara tidak langsung menciptakan suatu persaingan di bidang pemasaran. Semakin banyak konsumen yang merasa puas dengan barang atau jasa yang ditawarkan, maka volume penjualan di perusahaan tersebut pun akan meningkat. Faktor - faktor yang mempengaruhi volume penjualan ialah : (1) harga, (2) promosi, (3) produk yang ditawarkan, (4) saluran distribusi, (5) mutu. Harga menjadi salah satu pertimbangan utama ketika konsumen akan membeli suatu produk yang mereka inginkan. Adapun tujuan penelitian ini untuk mengetahui : (1) gambaran penetapan harga jual yang dilakukan oleh Tungku Café and Resto, (2) gambaran volume penjualan pada Tungku Café and Resto, (3) pengaruh penetapan harga jual terhadap volume penjualan di Tungku Café and Resto. Metode penelitian yang digunakan ialah metode deskriptif dengan menggunakan teknik pengumpulan data secara langsung melalui observasi dan wawancara. Hasil penelitian menunjukkan bahwa (1) penetapan harga jual menggunakan metode cost plus pricing mengalami fluktuatif dengan rata -rata margin sebesar $23 \%$, (2) volume penjualan mengalami fluktuatif dengan rata rata penjualan sekitar 38 produk yang terjual, (3) besarnya pengaruh penetapan harga jual terhadap volume penjualan sebesar $57,76 \%$ (koefisien determinasi). Hasil uji hipotesis diketahui bahwa $t_{\text {hitung }}$ lebih besar dari $t_{\text {tabel }}(3,697 \geq 2,228)$ artinya Ho ditolak dan $\mathrm{Hi}$ diterima. Hal ini menunjukkan bahwa penetapan harga berpengaruh signifikan terhadap volume penjualan

Kata kunci: Penetapan harga, cost plus pricing, volume penjualan.

Cara sitasi: Nurlela, I., Yanti, R. A. E., \& Aryansyah, F. (2021). Pengaruh Penetapan Harga Jual terhadap Volume Penjualan. J-KIP (Jurnal Keguruan dan IImu Pendidikan), 2 (3), 179-184. 


\section{PENDAHULUAN}

Perkembangan dunia usaha saat ini berjalan dengan pesat, yang secara tidak langsung menciptakan suatu persaingan dibidang pemasaran. Hal ini menuntut pelaku ekonomi untuk lebih peka, kritis dan reaktif terhadap perubahan, baik perubahan secara mikro maupun global. Langkah yang dapat ditempuh oleh pelaku ekonomi dalam mengatasi perkembangan dunia usaha ini adalah menciptakan dan mempertahankan konsumen. Keberhasilan suatu perusahaan, dapat dilihat dari loyalitas pelanggannya dalam membeli produk di perusahaan tersebut.Hal ini dapat dilihat dari grafik data penjualan barang atau jasa yang dimiliki perusahaan tersebut. Semakin banyak konsumen yang merasa puas dengan barang atau jasa yang ditawarkan oleh perusahaan, maka volume penjualan di perusahaan tersebut pun akan meningkat. Menurut Kotler, dalam (Agusri 2019) menyatakan bahwa: "Volume penjualan adalah barang yang terjual dalam bentuk uang untuk jangka waktu tertentu yang didalamnya mempunyai strategi pelayanan yang baik."

Menurut Kotler dalam (Putra, Cipta \& Yudiaatmaja, 2016) menyebutkan bahwa faktor - faktor yang mempengaruhi volume penjualan yaitu harga jual, produk yang di tawarkan, promosi yang dirancang, saluran distribusi, dan mutu. Tungku Café and Resto merupakan jenis usaha dagang dibidang makanan dan minuman. Dalam usaha meningkatkan volume penjualan, Tungku Café and Resto menetapkan strategi promosi produknya dengan menggunakan media sosial, ,dan juga spanduk. Namun hal ini menjadi salah satu faktor yang mempengaruhi volume penjualan, dikarenakan promosi yang dilakukan melalui media sosial tidak tersampaikan menyeluruh kepada masyarakat, dan spanduk ditempel hanya di bagian depan resto, hal ini sangat memungkinkan untuk konsumen tidak mengetahui produk atau penawaran baru dari perusahaan tersebut. Berdasarkan hasil observasi diperoleh daftar menu andalan Tungku Café and Resto Kota Banjar dan data penjualan selama satu tahun terakhir. Daftar menu andalan Tungku Café and Resto Kota Banjar disajikan pada tabel 1.

Tabel 1. Daftar Menu Andalan Tungku Café and Resto Kota Banjar

\begin{tabular}{|c|c|c|c|}
\hline No & $\begin{array}{l}\text { Kode } \\
\text { Produk }\end{array}$ & Nama Produk & Harga Jual Produk \\
\hline 1. & GDS & Grilled Tenderloin Steak & Rp. 54.500 \\
\hline 2. & GSS & Grilled Sirloin Steak & Rp. 52.500 \\
\hline 3. & CS & Chicken Steak & Rp. 35.500 \\
\hline 4. & CCB & Chicken Cordon Blue & Rp. 42.500 \\
\hline 5. & $\mathrm{BCB}$ & Beef Cordon Blue & Rp. 52.500 \\
\hline 6. & MLP & Meat loverPizza & Rp. 49.500 \\
\hline 7. & PSA & Supreme Pizza & Rp. 51.500 \\
\hline
\end{tabular}

Sumber : Tungku Cafe and Resto Kota Banjar

Tungku Café and Resto Kota Banjar memiliki beberapa jenis varian menu andalan. Berdasarkan tabel diatas, dapat dilihat bahwa Tungku Café and Resto Kota Banjar menawarkan beberapa jenis steak seperti grilled tenderloin steak,grilled sirloin steak, dan chicken steak. Selain itu, Tungku Café and Resto Kota Banjar juga menawarkan jenis produk berupa chicken cordon blue, beef cordon blue, meat lover pizza, dan supreme pizza.Data penjualan Tungku Café and Resto Kota Banjar disajikan pada tabel 2 . 
Tabel 2. Data Penjualan Tungku Cafe and Resto Kota Banjar Tahun 2020

\begin{tabular}{|c|c|c|c|c|}
\hline \multirow[b]{2}{*}{ Bulan } & \multicolumn{3}{|c|}{ Ranking Penjualan Produk } & \multirow{2}{*}{$\begin{array}{l}\text { Total volume } \\
\text { penjualan }\end{array}$} \\
\hline & $\begin{array}{l}\text { Grilled Tenderloin } \\
\text { steak }\end{array}$ & $\begin{array}{c}\text { Grilled Sirloin } \\
\text { Steak }\end{array}$ & Chicken Steak & \\
\hline Januari 2020 & Rp. 2.289 .000 & Rp. 682.500 & Rp. 357.500 & Rp. 3.329 .000 \\
\hline Februari 2020 & Rp. 2.180.000 & Rp. 525.000 & Rp. 520.000 & Rp. 3.225 .000 \\
\hline Maret 2020 & Rp. 2.507.000 & Rp. 630.000 & Rp. 325.500 & Rp. 3.462 .500 \\
\hline April 2020 & Rp. 654.000 & Rp. 420.000 & Rp. 130.000 & Rp. 1.204 .000 \\
\hline Mei 2020 & Rp. 218.000 & Rp. 105.000 & Rp. 0 & Rp. $\quad 323.000$ \\
\hline Juni 2020 & Rp. 2.616 .000 & Rp. 682.500 & Rp. 292.500 & Rp. 3.591 .000 \\
\hline Juli 2020 & Rp. 2.289.000 & Rp. 420.000 & Rp. 747.500 & Rp. 3.456 .500 \\
\hline $\begin{array}{l}\text { September } 2020 \\
\text { Oktober } 2020 \\
\text { November } 2020 \\
\text { Desember } 2020 \\
\text { Total Penjualan Ta }\end{array}$ & $\begin{array}{l}\text { Rp. } 2.234 .500 \\
\text { Rp } 3.706 .000 \\
\text { Rp. } 1.926 .000 \\
\text { Rp. } 2.834 .000 \\
20\end{array}$ & $\begin{array}{l}\text { Rp. } 315.000 \\
\text { Rp. } 735.000 \\
\text { Rp. } 682.500 \\
\text { Rp. } 472.500\end{array}$ & $\begin{array}{l}\text { Rp. } 292.500 \\
\text { Rp. } 585.000 \\
\text { Rp. } 227.500 \\
\text { Rp. } 445.000\end{array}$ & $\begin{array}{lr}\text { Rp. } & 2.842 .000 \\
\text { Rp. } & 5.026 .000 \\
\text { Rp. } & 2.836 .000 \\
\text { Rp. } & 3.751 .500 \\
\text { Rp. } & 35.846 .000\end{array}$ \\
\hline
\end{tabular}

Sumber : Tungku Cafe and Resto Kota Banjar (2021)

Berdasarkan tabel di atas, dapat kita simpulkan bahwa penjualan Tungku Cafe and Resto Kota Banjar mengalami fluktuatif.Dapat dilihat bahwa pada bulan Oktober 2020 merupakan tingkat penjualan tertinggi selama satu tahun terakhir. Pada bulan April 2020 hingga bulan Mei 2020 penjualan terus terjadi penurunan, namun pada bulan Juni 2020 Tungku Café and Resto Kota Banjar kembalimengalami peningkatan. Hal ini disebabkan oleh promosi yang dilakukan oleh Tungku Café and Resto Kota Banjar dan juga harga jual yang ditetapkan. Dengan harga jual yang tidak terjangkau oleh semua kalangan, menyebabkan volume penjualan mengalami fluktuatif di setiap produk yang ditawarkannya.

Mengikuti perubahan harga bahan baku dan biaya produksi lainnya, Tungku Cafe and RestoKota Banjar pun mengalami kesulitan dalam metode yang harus diambil untuk menetapkan harga jual yang mampu membuat masyarakat tertarik dan menjadi pelanggan yang memiliki sikap loyalitas yang tinggi, dan juga berpengaruh terhadap volume penjualan. Menurut Kotler dalam (Sunyoto, 2014) mendefinisikan bahwa : "Harga adalah sejumlah uang yang dibebankan pada suatu produk tertentu".

Seperti yang kita ketahui, bahwa harga menjadi salah satu pertimbangan utama ketika konsumen akan membeli suatu produk yang mereka inginkan. Dalam kondisi ekonomi saat ini, masih banyak para konsumen yang mencari produk dengan kualitas yang baik namun dengan harga yang terjangkau.Penetapan harga jual biasanya dilakukan perusahaan untuk menambah nilai atau besarnya biaya produksi yang diperhitungkan terhadap biaya yang dikeluarkan dalam memproses barang ataupun jasa.Tujuan penetapan harga merupakan hal utama yang harus diperhatikan dalam menentukan harga suatu produk Salah satunya bertujuan untuk merangsang permintaan konsumen. Menurut Putri (2017) Tujuan penetapan harga merupakan hal utama yang harus diperhatikan dalam mementukan harga suatu produk. Perusahaan harus memutuskan apa yang ingin dicapainya dengan menawarkan produk tertentu. Tujuan-tujuan ini mungkin berbeda-beda untuk setiap perusahaan. Tujuan tersebut antara lain :

1. Mendapatkan posisi pasar

2. Mencapai kinerja keunangan

3. Penentuan posisi produk

4. Merangsang permintaan

5. Mempengaruhi persaingan

Berdasarkan latar belakang diatas, tujuan yang ingin dicapai dalam penelitian ini mengetahui : 
1. Gambaran penetapan harga jual menu grilled tenderloin steak yang dilakukan oleh perusahaan Tungku Café and Resto Kota Banjar.

2. Gambaran volume penjualan menu grilled tenderloin steak pada perusahaan Tungku Cafe and Resto Kota Banjar.

3. pengaruh penetapan harga jual terhadap volume penjualan di Tungku Cafe and Resto Kota Banjar.

\section{METODE PENELITIAN}

\section{Metode Penelitian yang Digunakan}

Adapun aspek penelitian ini terdiri dari dua variable, dimana variable yang menjadi independen atau variabel bebas adalah penetapan harga jual, sedangka yang menjadi variabel dependen atau variabel terikat adalah volume penjualan.

Menurut Nawawi dalam Wahyu (2021) metode deskriptif adalah prosedur pemecahan masalah yang diselidiki dengan menggambarkan/ melukiskan keadaan subyek/obyek penelitian (seseorang, lembaga, masyarakat dan lain-lain) pada saat sekarang berdasarkan fakta-fakta yang tampak sebagaimana adanya.Dalam penelitian ini penulis menggunakan penelitian kuantitatif dengan metode deskriptif. Menurut Sugiyono (2017) "Metode penelitian deskriptif ini dilakukan untuk mengetahui keberadaan variable mandiri, baik hanya pada sat variabel atau lebih (variabel yang berdiri sendiri atau variabel bebas) tanpa membuat perbandingan variabel itu sendiri dan mencari hubungan dengan variabel lain". Sumber data yang digunakan berasal dari Tungku Café and Resto.Dalam penelitian ini teknik pengumpulan data yang digunakan adalah observasi dan wawancara. Teknik analisis data yang digunakan dapat dilakukan dengan menggunakan langkah-langkah diantaranya, Analisis Koefisien Korelasi Sederhana, Analisis Koefisien Determinasi dan uji Hipotesis dengan menggunakan Uji-t dan Uji f.

\section{HASIL DAN PEMBAHASAN}

Tungku Café and Resto Kota Banjar merupakan salah satu usaha yang bergerak di bidang kuliner, umumnya di bidang makanan western dan juga Indonesia. Akan tetapi peneliti tertarik untuk meneliti tentang makanan western yaitu grilled tenderloin steak, dikarenakan makanan yang memang terkenal atau andalan di Tungku Café and Resto ini.

Tungku Café and Resto Kota Banjar tidak menggunakan metode penetapan harga dalam menetapkan harga jual produknya.Tungku Café and Resto menjual Grilled Tenderloin Steak.dengan harga tetap yaitu Rp. 54.500 dengan hasil perhitungan jumlah biaya produksi modal awal dan margin yang diharapkan sebesar $25 \%$.

Adapun data rekapitulasi volume penjualan Tungku Café and Resto sebagai berikut.

\begin{tabular}{|c|c|c|c|}
\hline No & Bulan & Porsi & Persentasi \\
\hline 1 & Januari & 42 Porsi & - \\
\hline 2 & Februari & 46 Porsi & $9.5 \%$ \\
\hline 3 & Maret & 40 Porsi & $-13 \%$ \\
\hline 4 & April & 12 Porsi & $-70 \%$ \\
\hline 5 & Mei & 4 Porsi & $-66,6 \%$ \\
\hline 6 & Juni & 48 Porsi & $11 \%$ \\
\hline 7 & Juli & 42 Porsi & $-12.5 \%$ \\
\hline 8 & Agustus & 31 Porsi & $-26.2 \%$ \\
\hline 9 & September & 41 Porsi & $+3.2 \%$ \\
\hline 10 & Oktober & 68 Porsi & $+65.85 \%$ \\
\hline 11 & November & 36 Porsi & $-47 \%$ \\
\hline 12 & Desember & 52 Porsi & $+44.4 \%$ \\
\hline & nlah & 462 porsi & $-101.35 \%$ \\
\hline
\end{tabular}




\begin{tabular}{cccc}
\hline No & Bulan & Porsi & Persentasi \\
\hline & Rata - rata & 38 porsi & $-9.2 \%$ \\
\hline
\end{tabular}

Berdasarkan tabel diatas, penjualan di Tungku Cafe and Resto Kota Banjar bersifat fluktuatif. Bulan Oktober merupakan penjualan tertinggi pada tahun 2020 untuk menu Grilled Tenderloin Steak dengan rata - rata penjualan sekitar 38 produk yang terjual.

Berdasarkan hasil penelitian dapat dijelaskan bahwa penetapan harga jual mempunyai pengaruh dalam meningkatkan volume penjualan pada Tungku Café and Resto Kota Banjar. Hasil analisis koefisien korelasi sederhana yaitu sebesar 0,76 . Artinya nilai koefisien korelasi menunjukkan terdapat hubungan yang ditimbulkan antara penetapan harga terhadap volume penjualan grilled tenderloin steak pada Tungku Café and Resto Kota Banjar adalah kuat dan positif. Sehingga dapat disimpulkan bahwa hubungan yang ditimbulkan penetapan harga berada pada interval $(0,60-0,799)$, sehingga terdapat hubungan antara penetapan harga dengan volume penjualan grilled tenderloin steak. Berdasarkan analisis koefisien determinasi diperoleh pengaruh harga terhadap volume penjualan sebesar $57,76 \%$, sedangkan sisanya $42,24 \%$ dipengaruhi oleh variabel lain yaitu produk, distribusi, dan promosi.

Dalam memasarkan suatu produk baik barang maupun jasa, faktor lain seperti produk, distribusi, dan promosi sangat penting untuk dipertimbangkan karena semua itu dapat mempengaruhi permintaan akan barang atau jasa yang dijual oleh perusahaan. Produk yang bermutu dan berkualitas baik akan mempengaruhi konsumen dalam mempertimbangkan untuk membeli produk tersebut, kemudian dalam proses pendistribusian barang tersebut juga harus lancar dan juga harus menjangkau wilayah yang belum terjangkau dan dalam hal ini bidang promosi berperan untuk menyampaikan dan mengenalkan produk yang akan dipasarkan tersebut kepada konsumen sehingga para konsumen tertarik untuk membeli. Jadi antara produk, harga, distribusi, promosi dan mutu sangat berkaitan erat dan menunjang satu sama lain dalam proses pemasaran sehingga tujuan utama perusahaan yaitu memperoleh laba yang sebesar - besarnya dapat tercapai dengan baik.

Berdasarkan hasil pengujian hipotesis diperoleh nilai $t_{\text {hitung }}=3,697$ lebih besar dibandingkan dengan $t_{\text {tabel }}=2,228$ dengan tingkat kesalahan 0,05 . Dengan demikian $t_{\text {hitung lebih besar dari }} t_{\text {tabel }}$ $(3,697 \geq 2,228)$ maka keputusannya menolak hipotesis nol $(\mathrm{Ho})$ dan menerima hipotesis alternative $(\mathrm{Hi})$ berarti ada pengaruh antara penetapan harga $(X)$ terhadap volume penjualan $(\mathrm{Y})$ pada Tungku Café and Resto Kota Banjar.

Dari persamaan regresi linier sederhana yaitu $Y=(-52.16027088)+2.37020316 X$ menunjukkan adanya pengaruh antara penetapan harga $(X)$ terhadap volume penjualan $(Y)$ positif. Artinya jika variabel harga $(X)$ mengalami kenaikan 1 maka variabel volume penjualan $(Y)$ akan naik sebesar 2.37020316 dan sebaliknya jika variabel harga $(X)$ mengalami penurunan 1 maka variabel volume penjualan $(Y)$ akan mengalami penurunan sebesar 52.16027088. maka perhitungan uji $f$ dari regresi linier sederhana yang dihasilkan adalah $\mathrm{f}$ hitung $=13,67$ dan $\mathrm{f}$ tabel $=4,96$. Dengan demikian $\mathrm{f}$ hitung lebih besar dari $f$ tabel $(13,67>4,96)$, hal ini menunjukkan bahwa penetapan harga jual berpengaruh signifikan terhadap volume penjualan.

Hal ini sesuai dengan pendapat Kotler dalam (Putra, Cipta \& Yudiaatmaja, 2016) yang menyebutkan bahwa faktor - faktor yang mempengaruhi volume penjualan yaitu harga jual, produk yang di tawarkan, promosi yang dirancang, saluran distribusi, dan mutu. Hasil pengujian ini sejalan dengan penelitian terdahulu, yaitu hasil penelitian (Oktariansyah, 2016), (Rahmat, 2013) menunjukkan bahwa terdapat pengaruh yang signifikan antara penetapan harga terhadap volume penjulan dapat diterima. Sedangkan perbedaan antara penelitian ini dengan penelitian (Oktariansyah, 2016) terletak pada jenis penelitian. Oktariansyah menyebutkan bahwa penelitian yang ia lakukan adalah asosiatif.

\section{SIMPULAN}


Berdasarkan hasil penelitian dan pembahasan mengenai pengaruh penetapan harga jual terhadap volume penjualan (suatu kasus pada perusahaan Tungku Café and Resto Kota Banjar).Maka penulis menarik kesimpulan bahwa terdapat pengaruh yang signifikan antara penetapan harga jual terhadap volume penjualan. Dengan pengaruh harga jual terhadap volume penjualan sebesar $57,76 \%$, sedangkan sisanya dipengaruhi oleh faktor lain yaitu produksi, distribusi dan promosi.

\section{REKOMENDASI}

Berdasarkan simpulan yang telah dikemukakan sebelumnya, maka penulis mencoba memberikan saran yang diharapkan dijadikan bahan masukan bagi Tungku Café and Resto Kota Banjar di masa yang akan datang untuk meningkatkan volume penjualannya. Saran-sarang tersebut ialah sebagai berikut :

1. Tungku Café and Resto Kota Banjar bisa mempertahankan harga agar penjualannya dapat meningkat.

2. Bagi peneliti selanjutnya diharapkan untuk menambahkan variabel-variabel serta faktor-faktor lain yang dapat berpengaruh terhadap volume penjualan.

\section{UCAPAN TERIMA KASIH}

Pada kesempatan ini penulis mengucapkan terima kasih yang sebesar - besarnya kepada Pimpinan beserta staf Tungku Café and Resto Kota Banjar yang telah mendukung pelaksanaan penelitian ini.

\section{DAFTAR PUSTAKA}

Agusri. (2019). Pengaruh Harga Terhadap Volume Penjualan Pada Mebel Sinar Barokah Tanjung Karangan Kabupaten Muara Enim. Jurnal Media Wahana Ekonomika, Vol. 16 No.3, Oktober2019: 192-203

Oktariansyah, E. (2016) Aplikasi Sensor Water Flow G1/2 Pada Keran Air Otomatis Berbasis Arduino. Other Thesis, Politeknik Negeri Sriwijaya.

Putra, K. M., Cipta, W., \& Yudiaatmaja, F. (2016). Analisis Faktor-Faktor yang Mempengaruhi Volume Penjualan Pada UD. Wayan Fiber Glass Singaraja Tahun 2014..e-Jurnal Bisma Universitas Pendidikan Ganesha Vol. 4.

Putri, B. R. T. (2017). Manajemen Pemasaran, Denpasar : Swasta Nulus

Rahmat, H. (2013). Statistika Penelitian. Bandung: Pustaka Setia.

Sugiyono. (2017).Metode Penelitian Kuantitatif, Kualitatifdan R\&D. Bandung : Alfabeta CV.

Sunyoto. (2014). Dasar - Dasar Manajemen Pemasaran, Jakarta: Buku Seru

Wahyu, F. S. (2021). Pemanfaatan instagram sebagai media alternatif IPA dalam masa pembelajaran jarak jauh (pjj). J-KIP (Jurnal Keguruan dan Ilmu Pendidikan), 2 (2), 81-90. 